\title{
Makro İktisadi Göstergelerin Ekonomik Güven Üzerindeki Etkilerinin Analizi: Türkiye Örneği
}

\author{
İbrahim Aytekin ${ }^{1 *}$, Şeyma Bozkaya ${ }^{2}$ \\ ${ }^{1}$ Kırıkkale Üniversitesi, Sosyal Bilimler Enstitüsü, İktisat, Kırıkkale, Türkiye, ibrahimaytekin63@gamail.com \\ ${ }^{2}$ Nevşehir Hacı Bektaş Veli Üniversitesi, Sosyal Bilimler Enstitüsü İktisat, Nevşehir, Türkiye, Seymabozkaya@hotmail.com \\ Orcid: 0000-0002-3574-10071 Orcid: 0000-0001-8559-6608² \\ *Correspondence Author: ibrahimaytekin@gmail.com
}

Öz: İnsan hayatının neredeyse her aşamasında yer alan güven duygusu ülke ekonomileri için de önemli bir kavram haline gelmiştir. Yerli ve yabancı yatırımcıların bir ülkenin iktisadi yapısına güven duyması o ülkenin ekonomisinde işlerin yoluna gittiği anlamına gelmektedir. Ekonomisinde güveni tesis etmiş tüm ülkelerin büyümeye, yatırımlara ve kalkınmaya daha elverişli bir hale geleceği kabul edilmektedir. Dolayısıyla bu çalışmanın amacı, Türkiye'nin makro iktisadi göstergelerinin ekonomik güven üzerindeki etkilerinin analiz edilmesidir. Analizde 2008:M1-2019:M12 yılları arasındaki aylık veriler kullanılmıştır. Analizin ilk aşamasında değişkenlere birim kök testleri uygulanarak değişkenlerin durağanlık mertebeleri belirlenmiştir. Ardından belirlenen durağanlık mertebeleri doğrultusunda ARDL modelinin kullanılmasına karar verilmiş ve böylece değişkenlere ARDL sınır testi uygulanmıştır. Uygulanan ARDL sınır testi sonucunda değişkenler arasında uzun dönemli bir eşbütünleşme ilişkisinin var olduğu tespit edilmiştir. Analizin son aşasında tahmin edilen ARDL modelinin kısa ve uzun dönem katsayıları hesaplanmıştır. Sonuç olarak Türkiye'de uzun dönemde enflasyon, ihracat ve işsizlik değişkenleriyle ekonomik güven arasında negatif yönlü bir ilişki bulunurken; sanayi üretimi, reel döviz kuru ve ithalat değişkenleriyle ekonomik güven arasında ise pozitif yönlü bir ilişki bulunmuştur. Bu sonuç Türkiye'de makro iktisadi değişkenlerin uzun vadede ekonomik güven üzerinde pozitif ve negatif yönlü etkilere sahip olduğunu göstermektedir. Dolayısıyla Türkiye'nin bazı makroekonomik sorunların üstesinden gelebilmesi için gerekli olan şey, ekonomide güveni tesis ederek iktisadi büyümede istikrarı yakalamaktır.

Anahtar Kelimeler: ARDL, Ekonomik Güven, Makro İktisat, Türkiye, ARDL, Zaman Serisi 


\title{
Analysis Of The Effects Of Macro Economic Indicators On Economic Confidence: The Case Of Turkey
}

\begin{abstract}
The feeling of trust, which takes place in almost every stage of human life, has become an important concept for the economies of the country. The trust of local and foreign people or investors in the economic structure of a country means that things are going well in that country's economy. It is accepted that all countries that have established confidence in their economy will become more suitable for growth, investments and development. In this study, it is aimed to analyze the effects of macroeconomic indicators, which constitute the important economic dynamics of Turkey, on economic confidence. In the analysis, Turkey's monthly data between the years 2008: M1-2019: M12 were used. In the first stage of the analysis, unit root tests were applied to the variables and the stationarity levels of the variables were determined. Then, it was decided to use the ARDL model in line with the determined stationarity levels, and thus the ARDL boundary test was applied to the variables. As a result of the ARDL boundary test applied, it was determined that there is a long-term cointegration relationship between the variables. At the last stage of the analysis, the short and long term coefficients of the estimated ARDL model were calculated. As a result, while there is a negative relationship between the inflation, export and unemployment and economic confidence in the long term in Turkey; A positive relationship was found between industrial production, real exchange rate, import and economic confidence. This result shows that macroeconomic variables in Turkey have positive and negative effects on economic confidence in the long run. Therefore, what is necessary for Turkey to overcome some macroeconomic problems is to achieve stability in economic growth by establishing confidence in the economy.
\end{abstract}

Keywords: ARDL, Economic Confidence, Macro Economics, Turkey, Time Series

\section{Giriş}

Sosyal sistem içinde iletişimle şekillenen toplumsal yapıların sıkı bir ilişki kurmasını sağlayan unsur güvendir. Güven unsuru aynı zamanda sosyal sermaye olan bireyin ekonomik aktifler içinde yer almasını sağlamaktadır. Rasyonel bireyin ayırt edici bir özelliği olarak güven, bireylerin sadece davranışlarına etkisini değil aynı zamanda ekonomik olaylara olan etkisini de ortaya koymuştur. Makro açıdan bakıldığında güven ortamının sağlanmış olması istikrarlı bir ekonomik yapının oluşumuna sağlam zemin oluşturmaktadır. Güven unsuru mikro açıdan ise firmaların yarattığı katma değere önemli oranda etki etmektedir [1]. Güven unsurunun ekonomi açısından önemi son dönemde oldukça popüler hale gelmiştir. Bu durum ekonomide endeksler ile ölçülmeye çalışılmakta ve politika yapımında rehber oluşturabilmektedir.

Ekonomik güven endeksi, tüketicilerin ve üreticilerin ekonominin genel durumuna yönelik bilgi sahibi olma, aynı zamanda genel duruma yönelik değerlendirme, beklenti ve bu beklenti yönüne karşı almış oldukları tavırları ifade eden bir bileşik endeks olarak tanımlanmaktadır. Bu endeks farklı durumları ölçen alt endekslerden oluşmaktadır. Bu alt endekslerden oluşan ekonomik güven endeksinin bileşimi, tüketici güven göstergesi ile birlikte mevsimsel etkilerden arındırılmış imalat sanayi (reel kesim), hizmet, perakende ticaret ve inşaat sektörlerine endekslerin ağırlıklandırılarak birleştirilmesinden oluşmaktadır [2]. Bu endeks o toplumda yaşayan insanların ekonomiye karşı duydukları güveni temsil etmektedir. Dolayısıyla bu endeksler gelecek ekonomik görünümün öngörülmesi açısından oldukça önemlidir. Ekonomik güven endeksinin 100'ün üzerinde bir değer 
alması genel ekonomik duruma karşı toplumun olumlu bakış açısını, 100'ün altında kalması durumunda ise genel ekonomik duruma karşı toplumun kötümser bir bakış açısı içinde olduğu anlamina gelmektedir [3].

Keynes'in "hayvansal güdüler" yaklaşımı iş adamlarının gelecekteki iş beklentilerine duydukları güven ve "içgüdülerini" ifade etmesinden hareketle güvenin yatırımlara, ekonomik yapıya olan etkisine dikkat-çekmiştir. Hayvansal güdüler, genellikle bir risk unsuru olan yatırım kararlarının alınmasında yer alan riske de atıfta bulunabilmektedir. Ancak eğer insanlar bir durgunluk bekliyorlarsa, güven düşük olacak ve tasarruf artacaktır. Bu durum ekonomik daralmaya doğru bir yönelimle sonuçlanacaktır [4]. Keynes'in de dikkat çektiği üzere ekonomide riskler belirli bir düzeyde hesaplanabilir ama belirsizlik ekonomiyi asıl zora sokan durumdur. İnsanların beklentileri ve ekonomiye olan güvenleri oranında reel sektör ve makro değişkenler etkilenmektedir. Dolayısıyla ekonomide esas olan beklentileri olumlu yönde etkileyecek güven ortamının oluşturulmasıdır.

$\mathrm{Bu}$ çalı̧̧manın amacl, Türkiye'nin makro iktisadi göstergelerinin ekonomik güven üzerinde oluşturdukları etkilerinin yönünü ekonometrik yöntemlerle tespit etmektir. Bu doğrultuda çalışmada, Türkiye'nin 2008:M1-2019:M12 yılları arasındaki aylık ekonomik güven endeksiyle temel makro iktisadi göstergeler kullanılmıştır.

Literatürde genellikle güven endekslerinin makro değişkenlere ve yatırım araçlarına etkisi değerlendirilirken, bu çalışma feedback etkilere sahip olan ve makro değişkenlerin ekonomik güven endeksi üzerinde oluşturdukları etkiler analiz edilmiştir. Ayrıca bu çalışmanın analizinde kullanılan yöntem, dönem ve değişkenler bu çalışmayı diğer çalışmalardan ayrıştırmaktadır. Böylece bu çalışma bu yönleriyle literatürdeki çalışmalardan farklılık arz etmektedir. Son olarak çalışma giriş, literatür incelemesi, ampirik analiz ve sonuç bölümlerinden oluşmaktadır.

\section{Literatür İncelemesi}

Gelecek ekonomik durumların ve belirsizliklerin olası etkilerini değerlendirmek ve tahmin edebilmek adına güven endeksleri oldukça önemlidir. Riskin değil belirsizliğin daha belirgin olduğu ekonomilerde güven endekslerinin reel ekonomik göstergelere etkisinin görece daha etkili olması mümkündür. Bu bağlamda bu bölümde; ekonomik güven endeksi, ekonomik alt güven endeksleri ve ekonominin diğer göstergeleri arasındaki ilişkileri ele alan çalışmalara yer verilmiştir.

Kandır (2006), 2002:M2-2005:M6 dönemini kapsayan çalışmasında, tüketici güven endeksinin İMKB mali sektör şirketlerinin hisse senedi getirilerini tahmin etme düzeyini ölçmek adına 28 mali sektör şirketinin hisse senedi getirileri ile regresyon analizi yöntemini kullanarak model kurmuştur. Test sonucuna göre tüketici güven endeksinin mali sektör hisse senetlerinin büyük bir çoğunluğu için önemli bir faktör olduğu sonucuna ulaşılmıştır [5].

Korkmaz ve Çevik (2009), çalışmalarında İMKB 100 endeks getirisi ile reel kesim güven endeksi arasındaki nedensellik ilişkisini incelemişlerdir. İlk olarak İMKB 100 endeks getirisi ve güven endeksi EGARCH modeli ile tahmin edilmiştir. İkinci olarak ise EGARCH modelinden faydalanılarak elde edilen standart hatalar ve kareleri ile İMKB 100 endeks getirisi ve güven endeksi için nedensellik testi yapılmıştır. Analiz sonuçlarına göre, İMKB 100 endeksi getirisi ile güven endeksi arasında eş zamanlı ve çift yönlü bir nedensellik ilişkisinin varlı̆̆ tespit edilmiştir [6].

Çelik, Aslanoğlu ve Uzun (2010), çalışmalarında Türkiye ekonomisinde tüketici güveni ile finansal piyasalar arasındaki ilişkiyi analiz etmişlerdir. Çalışmada Ocak 2008 ile Ekim 2009 küresel kriz dönemi için haftalık veriler kullanılmıştır. Gelişmekte olan piyasalarda geleceğin daha çok riskli değil 
belirsiz olduğu varsayımı ile hareket etmişlerdir. Dolayısıyla böyle bir ekonomide tüketici güveninin, ekonomik gösterge olarak kabul edilmesi gerektiğini savunmaktadırlar. Bu varsayımdan hareketle tüketici duyarlılığını faiz oranları, döviz kurları ve borsa endeksi gibi yüksek frekanslı finansal piyasa değişkenlerinin bir fonksiyonu olarak modellemişlerdir. Analiz sonucuna göre tüketici güveniyle ilgili finansal piyasa değişkenleri arasında eşbütünleşme ilişkisinin varlığı tespit edilmiştir. Dolayısıyla, gelişen ekonomilerde tüketici güveni, sadece tüketicilerin ekonominin gelecekte alacağı duruma yönelik duyarlılığını yansıtmaktan ziyade, içsel bir değişken olarak görülmesi gerektiğini savunmuşlardır [7].

Çelik (2010), çalışmasında tüketici hissiyatının işlevsel kimliğini değerlendirmesi açısından alışılmadık bir şekilde ele almıştır. Ampirik sonuçlarda, tüketici güvenindeki hareketlerin döviz kurları, borsa endeksi, imalat sanayi endeksi ve iş ortamındaki eğilimle ölçülen beklentilerdeki değişikliklere bağlı olduğunu göstermektedir [8].

Topuz (2011), Türkiye üzerine yapmış olduğu çalışmasında, tüketici güven endeksi ve IMKB-100 endeksi arasındaki nedensellik ilişkisini 2004:01-2009:01 dönemlerini kapsayacak şekilde incelemiştir. Yapılan analiz sonucunda, hisse senedi fiyatlarından tüketici güvenine doğru tek yönlü bir Granger nedensellik ilişkisinin olduğu sonucuna varılmıştır [9].

Aarle ve Kappler (2012), yapmış oldukları çalışmalarında ekonomik duyarlılığın Euro bölgesi ülkelerindeki iş döngüsü dalgalanmalarını açıklayıp açıklamadığını incelemişlerdir. VAR modelini kullanarak, duyarlılık şoklarının üretim, perakende satışlar ve işsizlik gibi önemli makroekonomik değişkenler üzerinde etkisinin olduğu sonucuna ulaşmışlardır. Ayrıca ekonomik koşulların ve şokların ekonomik duyarlılı̆̆ı etkilediğine dair önemli kanıtlar bulmuşlardır [10].

Gürgür ve Kılınç (2015), Türkiye'de tüketici güven endeksi ile başlıca finansal ve makroekonomik değişkenler arasındaki kısa ve uzun dönemli ilişkiyi incelemişlerdir. Ampirik analiz sonuçlarına göre tüketici güveninin hem kısa dönemde hem de uzun dönemde döviz kuru, tüketici kredileri faizi, işsizlik oranı ve tüketici fiyatlarının etkisinde kaldığı ve kısa dönemde özellikle döviz kuru ve tüketici fiyatlarının etkisinin daha belirgin olduğu gözlenmiştir [11].

Tunalı ve Özkan (2016), Türkiye için 2004:01-2015:12 dönemini kapsayan çalışmalarında, tüketici fiyat endeksi ile tüketici güven endeksi arasındaki kısa ve uzun dönemli ilişkileri incelemişlerdir. Türkiye'de söz konusu dönemler arasında tüketici güven endeksi ile tüketici fiyat endeksi arasında uzun dönemli ilişkinin varlığı, kısa dönemde ise Tüketici fiyat endeksinden tüketici güven endeksine doğru bir nedensellik ilişkisinin var olduğu tespit edilmiştir [12].

Kale ve Akkaya (2016), VAR yöntemiyle tüketici güveni, reel sektör güveni ve beş farklı hisse senedi endeksi (toplam, finansal, endüstriyel, hizmet ve teknolojik) arasındaki ilişkileri incelemişlerdir. Michigan Üniversitesi Duyarlılık Endeksi, VIX volatilite endeksi ve GFK Almanya Tüketici İklimi Endeksi de uluslararası etkileri araştırmak için modellerle ilişkilendirilmiştir. Analiz sonuçları, tüketici güveninden hisse senedi getirilerine yönelik bir nedensellik ilişkisi olmadığını, ancak hisse senedi getirilerinin tüketici güvenini olumlu yönde etkilediğini göstermektedir. Öte yandan, reel sektör güven endeksi ile hisse senedi getirileri arasında çift yönlü nedensellik ilişkisinin olduğu ve her birinin diğerini belirli bir gecikme ile etkilediği tespit edilmiştir. Michigan Üniversitesi Tüketici Duyarlılığı Endeksi ve VIX volatilite endeksi, Türkiye'nin hemen hemen tüm borsa endeksleri üzerinde açıklayıcı güce sahipken, GFK Almanya Tüketici İklimi Endeksi'nin tüm modellerde herhangi bir hisse senedi getirisi üzerinde etkisine ulaşılamamıştır. Bu durum 
küreselleşmenin iç pazarlarda yer aldığını ve Türkiye'de, Almanya'dan ziyade ABD güven ortamının daha fazla hissedildiğini göstermesi açısından önemlidir [13].

Eyüpoğlu ve Eyüpoğlu (2017), 2012:M1-2016:M10 dönemini kapsayan çalışmalarında; BIST 100, BIST Sınai, BIST Hizmetler endeksleri ile ekonomik güven endeksi arasındaki uzun dönemli ilişkiyi Engle-Granger eşbütünleşme yönteminden faydalanarak analiz etmişlerdir. Yapılan analiz sonucunda söz konusu değişkenler arasında uzun dönemli bir ilişkinin var olduğu gözlenmiş ve her üç endeksin de ekonomik güven endeksinin Granger nedeni olduğu kanıtlanmıştır [14].

Evci (2019), 2007:M1-2019:M6 dönemini kapsayan çalışmasında, ekonomik güven endeksi ile BİST 100, dolar ve altın fiyatları arasındaki ilişkiyi Toda-Yamamoto metoduyla incelemiştir. Yapılan analizi sonucunda, BİST100 endeksinden ekonomik güven endeksine doğru bir nedensellik ilişkisinin olmadığı, ekonomik güven endeksinden BİST100 endeksine doğru tek yönlü bir ilişkinin varlığı tespit edilmiştir. Buna karşın USD/TL kurundan ekonomik güven endeksine doğru tek yönlü nedensellik bulunurken, altın fiyatları ile ekonomik güven endeksi arasında bir nedensellik ilişkisine rastlanmamıştır [15].

Aytekin ve Doyar (2019), 2008:M1-2019:M3 dönemleri arasında Türkiye'nin aylık reel döviz kuru, toplam sanayi üretimi ile tüketici güven endeksini analiz etmişlerdir. Yapılan analiz sonucunda değişkenler arasında uzun dönemli ilişkinin varlığına rastlanmıştır. Granger nedensellik testi sonuçlarına göre ise döviz kuru ile sanayi üretimi arasında çift yönlü bir nedensellik ilişkisine rastlanırken, döviz kurundan tüketici güven endeksine doğru ise tek yönlü bir nedensellik ilişkisinin var olduğu tespit edilmiştir [16].

Güngör (2019), çalışmasında 2007-2017 dönemlerine ait ekonomik güven endeksi ile yatırım araçlarından ABD doları ile altının reel getirileri arasındaki nedensellik ilişkisini incelemiştir. Yapılan Granger nedensellik testinden elde edilen sonuçlara göre her iki yatırım aracının getirisi ile ekonomik güven endeksi arasında tek yönlü bir nedensellik ilişkisine rastlanmıştır. Ayrıca ABD dolarının reel getirisi ile ekonomik güven endeksi arasında negatif; altının reel getirisi ile ekonomik güven endeksi arasında ise pozitif korelasyona rastlanmıştır [17].

Çankaya ve Alp (2019), Türkiye ekonomisi için 2007:M1-2017:M12 dönemini kapsayan çalışmalarında, sanayi üretim düzeyini etkileyen makroekonomik faktörlerden farklı olarak üreticileri ve tüketici güven endeksleri aracılığı ile ekonomiye olan güvenin üretim seviyesi üzerine etkisini incelemişlerdir. Çalışmada küresel kriz dönemi içerisinde olduğundan 2007-2010 dönemi ve kriz sonrası görece istikrarlı dönem olarak değerlendirilen 2010-2017 dönemleri olarak iki farklı gruba ayrılarak incelenmiştir. Yapılan VECM analiz sonucunda, tüketici güven endeksinin etkisinin sanayi üretimini belirgin olarak etkilediği gözlenmiştir. Buna karşın reel kesim güven endeksinin ise tüketici güven endeksine göre daha sınırlı düzeyde olduğu sonucuna ulaşılmıştır. Her iki analiz dönemi için kriz dönemleri değerlendirildiğinde güven endekslerinin etkilerinin daha net bir şekilde hissedildiği tespit edilmiştir [18].

Aytekin (2020), 2008:M1-2020:M3 dönemini kapsayan çalışmasında, Türkiye'nin toplam sanayi üretimi, ekonomik güven endeksi ve reel döviz kuru göstergeleri arasındaki ilişkiyi analiz etmiştir. Yapılan analiz sonucunda; reel döviz kuru, toplam sanayi üretimi ve ekonomik güven değişkenlerinin her birinde ya da hepsinde meydana gelecek bir gelişmenin Türkiye ekonomisini iktisadi yönden etkileyebileceği sonucuna ulaşılmıştır [18].

Literatür özetinden de anlaşıldığı üzere, ekonomik güven ve alt endeksleriyle diğer iktisadi ve finansal değişkenler arasında genel olarak sıkı bir ilişkinin olduğu sonucuna varılmıştır. Dolayısıyla 
bu sonuçlar, güven endekslerinin ekonomik performans üzerinde belirgin etkilerinin olduğunu ispatlar niteliktedir.

\section{Veri Seti ve Ekonometrik Yöntem}

Ekonometrik analizde Türkiye'nin 2008:M1-2019:M12 yılları arasındaki aylık veriler kullanılmıştır. Veriler Türkiye Cumhuriyeti Merkez Bankasının (TCMB)[19] EVDS sistemi ile Türkiye İstatistik Kurumunun (TUIK) istatistikler veri tabanından temin edilmiştir. Analizde kullanılan değişkenlerin tamamı Tablo 1'de verilmiş olup, değişkenlerin logaritmik dönüşümleri yapılmıştır.

Tablo 1. Analizde Kullanılan Değişkenler ve Kaynak

\begin{tabular}{lll}
\hline Değişken Adı & Değişkenin Kısa Adı & Kaynak \\
\hline Ekonomik Güven Endeksi & LNEGE & TUIKK \\
Enflasyon & LNLENF & TCMB \\
İşsizlik & LNişZ & TCMB \\
İhracat Birim Değer Endeksi & LNİHR & TUIK \\
İthalat Birim Değer Endeksi & LNİTH & TUIK \\
Reel Döviz Kuru & LNRDK & TCMB \\
Toplam Sanayi Üretim Endeksi & LNTSU & TCMB \\
\hline
\end{tabular}

Çalışmada ekonometrik analize başlamadan önce değişkenlerin istatistiki özetlerine bakılmıştır. Ardından ekonometrik analize geçilmiş ve ekonometrik analizin ilk aşamasında serilerin durağan olup olmadığına The Augumented Dickey Fuller (ADF) ve Philips-Perron (PP) birim kök testleri bakılmıştır. Birim kök testlerinin sonuçları doğrultusunda serilere, otoregresif dağıtılmış gecikme (ARDL) sınır testinin uygulanmasına karar verilmiştir. Analizde ARDL sınır testinin kullanılmasına karar verildikten sonra ARDL modeli tahmin edilmiş ve tahmin edilen bu modelin sağlıklı bir şekilde çalışıp çalışmadığını test etmek için ise bu modele birtakım tanısal sınama testleriyle CUSUM testi uygulanmıştır. Tahmin edilen modelin bu testlerden başarıyla geçmesinin ardından değişkenler arasında bir eşbütünleşme ilişkisinin olup olmadığını incelemek için ARDL tahmin modeline F sınır testi uygulanmıştır. Değişkenler arasında uzun dönemli bir eşbütünleşme ilişkisinin tespit edilmesinin ardından kısa ve uzun dönem katsayıları tahmin edilmiş ve analiz bu şekilde tamamlanmıştır.

\section{Ekonometrik Analiz Sonuçları}

Ekonometrik analizde başlangıç olarak değişkenlerin tanımlayıcı istatistiki özetleri oluşturulmuştur. Bu bağlamda Tablo 2'de modele yönelik olarak gözlem sayıları, ortalama, standart sapma, varyans, minimum ve maksimum değerleri ifade eden tanımlayıcı istatistiki özetlere yer verilmiştir.

Tablo 2. Değişkenlerin Tanımlayıcı İstatistiki Özeti

\begin{tabular}{lcccccc}
\hline Değişkenler & $\begin{array}{c}\text { Gözlem } \\
\text { Sayıs }\end{array}$ & Ortalama & $\begin{array}{c}\text { Standart } \\
\text { Sapma }\end{array}$ & Varyans & $\begin{array}{c}\text { Minimum } \\
\text { Değer }\end{array}$ & $\begin{array}{c}\text { Maksimum } \\
\text { Değer }\end{array}$ \\
\hline LNEGE & 144 & 4.577 & 0.116 & 0.013 & 4.107 & 4.744 \\
LNLENF & 144 & 2.199 & 0.343 & 0.118 & 1.382 & 13.228 \\
LNIŞZ & 144 & 2.35 & 0.160 & 0.026 & 1.988 & 2.694 \\
\hline
\end{tabular}




\begin{tabular}{lllllll} 
LNİHR & 144 & 4.615 & 0.083 & 0.007 & 4.498 & 4.853 \\
LNİTH & 144 & 4.592 & 0.118 & 0.014 & 4.379 & 4.847 \\
LNRDK & 144 & 4.614 & 0.155 & 0.024 & 4.134 & 4.847 \\
LNTSU & 144 & 4.484 & 0.223 & 0.049 & 3.921 & 4.867 \\
\hline
\end{tabular}

Tablo 2'den de anlaşıldığı üzere gözlem sayısı modeli kurmak için yeterlidir. Ayrıca değişkenlerin standart sapma ve varyansları incelendiğinde ortalamadan çok sapmadıkları da anlaşılmaktadır. Nihayetinde özet istatistikler değişkenlerin analize uygun olduklarını göstermektedir. Bundan sonraki aşama değişkenlerin durağanlık mertebelerinin test edildiği birim kök testi analizlerinde oluşmaktadır.

\subsection{Birim Kök Test Sonuçları}

Zaman serisi analizlerinde birim kök testleri, değişkenlerin birim kök içerip içermediklerinin yani durağan olup olmadıklarının test edildiği analiz modelleridir. Dolayısıyla bu çalışmada değişkenlerin durağan (birim kök içerip içermedikleri) olup olmadıklarını tespit etmek için ADF ve PP birim kök testleri kullanılmış ve ulaşılan sonuçlar aşağıda gösterilern Tablo 3 'te verilmiştir.

Tablo 3. ADF ve PP Birim Kök Testi Sonuçları

\begin{tabular}{|c|c|c|c|c|c|c|c|c|c|}
\hline \multirow{3}{*}{ Seviye } & \multirow{3}{*}{ Değişkenler } & \multicolumn{4}{|c|}{ ADF } & \multicolumn{4}{|c|}{ PP } \\
\hline & & \multicolumn{2}{|c|}{ Sabit } & \multicolumn{2}{|c|}{ Sabit ve Trend } & \multicolumn{2}{|c|}{ Sabit } & \multicolumn{2}{|c|}{ Sabit ve Trend } \\
\hline & & t-statist. & Prob. & t-statist. & Prob. & t-statist. & Prob. & t-statist. & Prob. \\
\hline \multirow{10}{*}{$\begin{array}{l}\text { Düzey } \\
\text { Değer }\end{array}$} & LNEGE & -2.230 & 0.196 & -2.212 & 0.479 & -2.702 & 0.076 & $-2,693$ & 0.241 \\
\hline & LNLENF & -2.774 & 0.065 & $-2.999 * *$ & 0.040 & $-2,483$ & 0.122 & -2.999 & 0.136 \\
\hline & LNİ̧̧Z & $-3.351^{* *}$ & 0.020 & $-3.514^{* *}$ & 0.042 & -2.002 & 0.286 & -2.201 & 0.485 \\
\hline & LNIHR & -2.460 & 0.127 & -3.091 & 0.112 & -2.056 & 0.276 & -2.665 & 0.253 \\
\hline & LNİTH & -1.557 & 0.502 & -2.071 & 0.557 & -1.593 & 0.483 & -2.178 & 0.498 \\
\hline & LNRDK & -0.612 & 0.863 & -2.455 & 0.350 & -1.001 & 0.750 & -2.706 & 0.236 \\
\hline & LNTSU & -2.433 & 0.134 & -2.514 & 0.321 & -2.372 & 0.152 & $-8.174^{*}$ & 0.000 \\
\hline & $\triangle \mathrm{LNEGE}$ & $-9.063^{*}$ & 0,000 & $-9.031^{*}$ & 0,000 & $-9.066^{*}$ & 0,000 & $-9.035^{*}$ & 0,000 \\
\hline & $\triangle \mathrm{LNLENF}$ & $-7.566^{*}$ & 0,000 & $-7.815^{*}$ & 0,000 & $-8.889^{*}$ & 0,000 & $-8.854^{*}$ & 0,000 \\
\hline & $\Delta$ LNİŞZ & $-3.050^{* *}$ & 0.033 & $-3.490^{* *}$ & 0.045 & $-5.069^{*}$ & 0,000 & $-6.942 *$ & 0,000 \\
\hline \multirow{4}{*}{$\begin{array}{c}\text { Birinci } \\
\text { Fark }\end{array}$} & $\triangle \mathrm{LNIHR}$ & $-6,773^{*}$ & 0,000 & $-6.747^{*}$ & 0,000 & $-6.683^{*}$ & 0,000 & $-6.654^{*}$ & 0,000 \\
\hline & $\Delta \dot{I N I T H}$ & $-7.730^{*}$ & 0,000 & $-7.702^{*}$ & 0,000 & $-7.961^{*}$ & 0,000 & $-7.943^{*}$ & 0,000 \\
\hline & $\triangle \mathrm{LNRDK}$ & $-10.047^{*}$ & 0,000 & $-10.035^{*}$ & 0,000 & $-8.935^{*}$ & 0,000 & $-8.898^{*}$ & 0,000 \\
\hline & $\triangle \mathrm{LNTSU}$ & $-4.716^{*}$ & 0,000 & $-4.939^{*}$ & 0,000 & $-41.000 *$ & 0,000 & $-40.085^{*}$ & 0,000 \\
\hline
\end{tabular}

*: \%1 ve **: \%5 önem seviyesinde istatistiki açıdan anlamlı.

Tablo 3'ten görüldüğü üzere işsizlik (LNİ̧Z) değişkeni ADF birim kök testinin her iki modeline göre düzeyde durağan yani I(0) iken PP birim kök testinin her iki modeline göre ise birinci farkta durağan yani I(1)'dir. Analizde kullanılan bir diğer değişken olan enflasyon (LNENF) ADF birim kök testinin sabitli modeline göre düzeyde durağan yani I(0) iken birim kök testlerinin diğer tüm modelleri için ise birinci farkta durağan, yani I(1)'dir. Dolayısıyla analizde kullanılan değişkenlerden işsizlik ve enflasyonun durağanlık dereceleri bazı birim kök testlerinin modellerine göre I(0) iken bazı birim kök testlerinin modellerine göre ise I(1) oldukları anlaşılmıştır. İşsizlik ve enflasyon dışında kalan 5 değişkenin ise ADF ve PP birim kök testlerinin tüm modelleri için birinci farkta durağan yani I(1) 
oldukları anlaşılmıştır. Sonuç olarak yapılan ADF ve PP birim kök testi sonuçlarına göre bazı değişkenlerin durağanlık derecelerinin $\mathrm{I}(0)$, bazılarının ise $\mathrm{I}(1)$ olduğu tespit edilmiştir. Buradan hareketle analizde ARDL sınır testi modelinin kullanılmasına karar verilmiştir.

\subsection{ARDL Modeli ile Tanisal Sinama ve CUSUM Testleri}

Birim kök testlerinin sonuçları doğrultusunda ARDL modelinin kullanılmasına karar verilmiş ve bu bağlamda ARDL(2.3.2.1.1.2.3) modeli tahmin edilmiştir. Model Akaike (AIC) bilgi kriterlerine göre tahmin edilmiş ve modelde kullanılan gecikme uzunluğu otomatik olarak 4 seçilmiştir. Tahmin edilen bu modelde; bağımlı değişken olarak ekonomik güven endeksi seçilmiştir. Ekonomik güven endeksinin birinci farkta durağan yani I(1) olduğu tespit edilmiştir.

ARDL modeli tahmin edildikten sonra bu modelde otokorelasyon ve değişen varyans sorunun olup olmadığı ve modelin normal dağılama uyup uymadığını sınamak için modele birtakım sınama testleri uygulanmış ve ulaşılan sınama testlerinin sonuçları aşağıda gösterilen Tablo 4 'te verilmiştir.

Tablo 4. Tanısal Sınama Test Sonuçları

\begin{tabular}{|c|c|}
\hline \multicolumn{2}{|c|}{ Otokorelasyon LM Testi } \\
\hline F-İstatistiği & 0.045 \\
\hline Olasılık (P) & 0.957 \\
\hline \multicolumn{2}{|c|}{ Değişen Varyans Testi (Breusch-Pagan-Godfrey) } \\
\hline F-İstatistiği & 1.275 \\
\hline Olasılık (P) & 0.209 \\
\hline \multicolumn{2}{|c|}{ Normallik Testi (Jarqua-Bera) } \\
\hline Jarqua-Bera & 0.118 \\
\hline Olasılık (P) & 0.943 \\
\hline
\end{tabular}

Yapılan sınama testlerinde otokorelasyon LM testi ile değişen varyans testinin Tablo 4 'te verilen olasılık değerleri incelendiğinde, bu değerlerin her iki test için de \%5 önem seviyesinden büyük olduğu anlaşılmıştır. Yani her iki testin yokluk hipotezi olan $\mathrm{H}_{0}$ reddedilmemektedir. Bu durum tahmin edilen ARDL modelinde otokorelasyon sorunu ile değişen varyans sorununun olmadığ anlamına gelmektedir. Ardından modelin normal dağılıma uyup uymadığı kontrol edilmiş ve Tablo 4'te verilen normal dağılımın olasılık değerinin \%5 önem seviyesinden büyük olduğu anlaşılmıştır. Yani normal dağılımın yokluk hipotezi olan $\mathrm{H}_{0}$ reddedilmemektedir. Bu sonuca göre tahmin edilen ARDL modelinin normal dağılıma da uyduğu tespit edilmiştir. Böylece sınama testlerinden başarıyla geçen ARDL tahmin modelinde yapısal kırılmaların olup olmadığının tespit edilmesi için modele CUSUM ve CUSUM kare testleri uygulanmış ve elde edilen sonuçlar aşağıda gösterilen Şekil 1'de verilmiştir. 

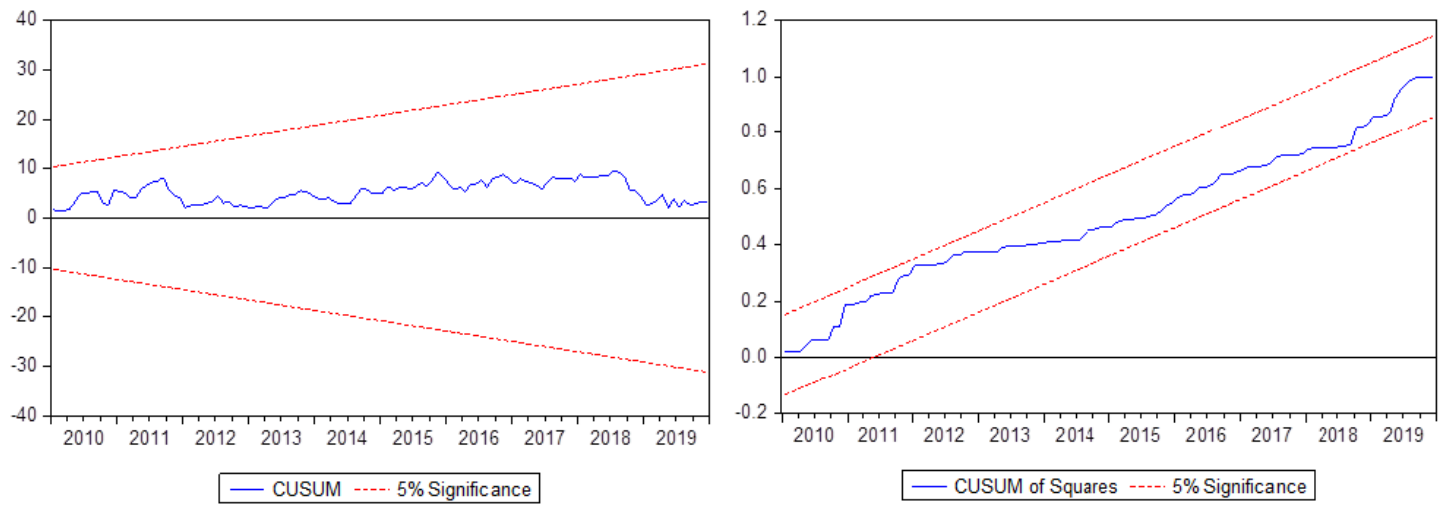

Şekil 1. CUSUM ve CUSUM Kare Testi

Yapılan CUSUM ve CUSUM kare testlerinde tahminlerin \%95 güven sınırları içerisinde dalgalandıkları Şekil 1'de ki grafiklerde görülmektedir. Tahminlerin güven aralığı sınırları içerisinde dalgalanmaları, modelde kırılmaların olmadığı ve tahmin edilen parametrelerin istikrar koşulunu sağladıkları anlamına gelmektedir. Böylece sınama testlerinden başarıyla geçen model CUSUM ve CUSUM kare testlerinden de başarıyla geçmiştir. Analizin bundan sonraki aşamasında değişkenler arasında eşbütünleşme ilişkisinin olup olmadığının test edildiği ARDL sınır testi sonuçlarına yer verilmiştir.

\subsection{ARDL Sinır Testi Sonuçları}

Pesaran ve arkadaşları (2001), değişkenler arasındaki eşbütünleşme ilişkisinin tespit edilmesinde değişkenlerin $\mathrm{I}(0)$ veya $\mathrm{I}(1)$ olabileceği gibi değişkenlerin bir kısmımım $\mathrm{I}(0)$ bir kısmının ise $\mathrm{I}(1)$ olduğu durumlarda da analizlerin yapılabileceği ARDL sınır testini önermişlerdir. Pesaran ve arkadaşları burada I(0) için bir alt sınır, I(1) için ise bir üst sınır değeri belirlemişlerdir. Eğer bulunan F istatistik değeri $\mathrm{I}(0)^{\prime}$ ın altındaysa değişkenler arasında kesin olarak bir eşbütünleşme ilişkisinin olmadığına karar verilir. Fakat bulunun F istatistik değeri I(1) sınır değerinin üzerinde ise bu sefer değişkenler arasında bir eşbütünleşme ilişkisinin var olduğuna kesin olarak kara verilir. Son olarak bulunan F istatistik değeri I(0) ile I(1) sınır değerleri arasında kalıyorsa bu sefer değişkenler arasında bir eşbütünleşme ilişkisi hakkında kesin bir sonuca varılamayacaktır [20]. Bu bağlamda bu çalışmada yapılan ARDL sınır testinin sonuçları aşağıda gösterilen Tablo 5'te verilmiştir.

Tablo 5. ARDL Sınır Testi Sonuçları

\begin{tabular}{ccc}
\hline Tahmin Edilen Eşitlik: LNEGE= f(LNENF, LNIŞZ, LNIHHR, LNİTH, LNRDK, LNTSU) \\
\hline F-istatistik Değeri & \multicolumn{2}{c}{ Kritik değer } \\
8.71 & Alt Sınır I $(0)$ & Üst Sınır I(1) \\
$\% 1$ & 3.15 & 4.43 \\
$\% 5$ & 2.45 & 3.61 \\
$\% 10$ & 2.12 & 3.23 \\
\hline
\end{tabular}

Tablo 5'te görüldüğü üzere ARDL sinır testinin F istatistik değeri 8.71 olarak bulunmuştur. Bu F istatistik değeri Tablo 5'te yer alan \%5 önem sevisinin üst sınır değeri olan 3.61'den büyük (F>I(1)) bir değer olduğu için yokluk hipotezi $\mathrm{H}_{0}$ reddedilmektedir. Elde edilen bu sonuç, Türkiye'de makro iktisadi değişkenler ile ekonomik güven arasında bir eşbütünleşme ilişkisinin var olduğunu 
göstermektedir. Böylece tahmin edilen ARDL modelinin sınır testi sonuçları, makro iktisadi değişkenlerin uzun vadede ekonomik güveni etkileyebilen değişkenler olduklarını göstermektedir. Değişkenler arasında uzun dönemli bir ilişkinin tespit edilmesinden sonra modelin kısa ve uzun dönem katsayıları hesaplanmıştır. Ulaşılan sonuçlar aşağıda gösterilen Tablo 6 ve Tablo 7'de verilmiştir.

Tablo 6. Hata Düzeltme Modeli (HDM) ve Kısa Dönem Test Sonuçları

\begin{tabular}{lcccc}
\hline \multicolumn{1}{c}{ Değişken } & Katsayı & Standart Hata & t-istatistik (t) & Olasıllik (P) \\
\hline D(LNEGE(-1)) & 0.139 & 0.081 & 1.711 & 0.089 \\
D(LNENF) & -0.057 & 0.021 & -2.624 & 0.009 \\
D(LNENF(-1)) & 0.013 & 0.032 & 0.413 & 0.679 \\
(LNENF(-2)) & 0.042 & 0.021 & 1.921 & 0.057 \\
D(LNiHR) & 0.140 & 0.226 & 0.617 & 0.540 \\
(LNiHR(-1)) & 0.705 & 0.193 & 3.642 & 0.000 \\
D(LNişZ) & -0.121 & 0.060 & -2.010 & 0.046 \\
(LNiTH) & 0.150 & 0.197 & 0.763 & 0.446 \\
D(LNRDK) & 0.330 & 0.089 & 3.683 & 0.000 \\
D(LNRDK(-1)) & 0.245 & 0.097 & 2.511 & 0.013 \\
D(LNTSU) & -0.030 & 0.031 & -0.972 & 0.333 \\
D(LNTSU(-1)) & 0.041 & 0.034 & 1.236 & 0.219 \\
D(LNTSU(-2)) & -0.101 & 0.029 & -3.458 & 0.000 \\
CointEq(-1) & -0.249 & 0.047 & -5.269 & 0.000 \\
\hline
\end{tabular}

Tablo 6 'da -0.249 olarak bulunan hata düzeltme katsayısının olasılık ve $t$ test istatistik değerleri incelendiğinde her iki değerinde istatistiki açıdan anlamlı olduğu görülmektedir. Bu sonuç hata düzeltme modelinin sorunsuz bir şekilde çalıştığı anlamına gelmektedir. Bununla birlikte hata düzeltme katsayısının - 0.249 olarak tespit edilmesi kısa dönem dengesinde meydana gelen sapmaların yaklaşık olarak $1 /(|-0.249|)=4.1$ aylık bir zamanda diliminde yeniden uzun dönem dengesine ulaşacağını ifade etmektedir.

Ayrıca Tablo 6'da kısa dönem katsayılarına da yer verilmiştir. Kısa dönem sonuçlarına göre; enflasyon, işsizlik ve ekonomik güven arasında anlamlı bir ilişki bulunurken, bu ilişkinin yönü negatiftir. İthalat ile ekonomik güven arasında pozitif yönlü fakat istatistiki açıdan anlamlı olmayan bir ilişki bulunurken; reel döviz kuru ile ekonomik güven arasında ise pozitif ve istatistiki açıdan anlamlı bir ilişki bulunmuştur. İhracata baktığımızda ise ihracat ile ekonomik güven arasında pozitifli yönlü bir ilişki bulunurken bu ilişki ancak birinci gecikmede anlamlı hale gelmektedir. Son olarak kısa dönemde toplam sanayi üretimi ile ekonomik güven arasında negatif yönlü bir ilişki bulunurken bu ilişki ancak ikinci gecikmede anlamlı hale gelmektedir. Kısa dönem analiz sonuçlarından sonra analizin son aşamasını oluşturan uzun dönem katsayıları aşağıda gösterilen Tablo 7'de verilmiştir.

Tablo 7. Uzun Dönem Test Sonuçları

\begin{tabular}{lcccc}
\hline Değişken & Katsayı & Standart Hata & t-istatistik (t) & Olasılık (P) \\
\hline LNENF & -0.303 & 0.059 & -5.150 & 0.000 \\
LNİHR & -3.318 & 0.690 & -4.816 & 0.000 \\
LNİ̧Z & -0.080 & 0.116 & -0.690 & 0.491 \\
\hline
\end{tabular}




\begin{tabular}{|c|c|c|c|c|}
\hline LNİTH & 2.139 & 0.428 & 4.996 & 0.000 \\
\hline LNRDK & 0.395 & 0.177 & 2.230 & 0.028 \\
\hline LNTSU & 0.410 & 0.110 & 3.729 & 0.000 \\
\hline $\mathrm{C}$ & 7.276 & 2.126 & 3.423 & 0.001 \\
\hline
\end{tabular}

Tablo 7'de yer alan makro iktisadi değişkenlerin ekonomik güven üzerindeki uzun dönemli sonuçları incelendiğinde, işsizlik değişkeni dışındaki tüm değişkenlerin \%5 önem seviyesinde istatistiki açıdan anlamlı oldukları görülmektedir. Bu bağlamda enflasyon ve ihracat ekonomik güven üzerinde negatif yönlü bir etkiye sahipken bu etki \%5 önem seviyesinde anlamlıdır. İşsizlik ise ekonomik güven üzerinde negatif yönlü bir etkiye sahipken bu etki \%5 önem seviyesinde anlamsızdır. Dolayısıyla Türkiye'de enflasyonda görülen \%1'lik bir artış ekonomiye olan güvende \%0.30'luk bir düşüşe neden olmaktadır. İhracatta görülen \%1'lik bir artış ise ekonomiye olan güvende \%3.31'lik bir düşüşe neden olmaktadır. İhracatta görülen bu negatif yönlü etkinin temel nedenleri; insanların ihracat artışıyla birlikte ihraç edilen ürünlerin iç piyasada arzının daralacağı ve bu arz daralmalarının ihraç edilen ürünlerin iç piyasada fiyatlarının yükselebileceği kaygısına neden olması ekonomiye olan güveni olumsuz yönde etkileyebilmektedir. Ayrıca ihracat artışının sebeplerinden biri olan kur artışlarına bağlı olarak ulusal paranın değer kaybetmesi, ekonomide işlerin yolunda gitmediğini ve ekonominin olası bir enflasyonla karşı karşıya kalabileceği kaygısı oluşturması, Türkiye' de insanların ekonomiye olan güvenlerini sarsmaktadır.

Tablo 7 'de yer alan ithalat, reel döviz kuru ve toplam sanayi üretimiyle ekonomik güven arasında ise pozitif yönlü ve istatistiki açıdan anlamlı bir ilişkinin olduğu tespit edilmiştir. Böylece ithalatta görülen \%1'lik bir artış ekonomiye olan güvende \% 2.14'luk bir artışa neden olmaktadır. Türkiye üretimde ithal ara girdilere bağımlı bir ülke olduğu için ithalat üretim artışının buna bağlı olarak da büyümenin itici bir gücüdür. Böylece ithalatla birlikte üretimin artması yeni istihdam alanları yaratırken, işsizliği düşürmekte ve gelirleri yükseltebilmektedir. Bu durum ise ekonomiye olan güveni de arttırmaktadır. Analizin bir diğer değişkeni olan reel döviz kurunda görülen \%1'lik bir artış ise ekonomiye olan güvende \% 0.39 'luk bir artışa neden olmaktadır. Türkiye'de dövizin kısa vadeli getirilerinin yüksek olmasından dolayı reel döviz kurunda görülen artışlar insanların paralarını dövize yatırmalarına neden olmakta ve dolayısıyla bu durum gelir getirici bir etkiye sahip olduğu için ekonomiye olan güveni de arttırmaktadır. Son olarak toplam sanayi üretiminde görülen \%1'lik bir artış ekonomiye olan güvende \% 0.41'lik bir artışa neden olmaktadır. Yani Türkiye'de üretim artışları ve buna bağlı olarak iktisadi büyüme ekonomiye olan güveni arttırmaktadır. Çünkü üretimdeki artış ve buna bağlı olarak iktisadi büyüme yeni istihdam alanları yaratırken, gelir ve reel ücretlerinde artmasına katkı sağlamaktadır.

\section{Sonuç ve Değerlendirme}

Ekonomilerde güven istikrarlı büyümenin ve dış yatırımcıyı çekmenin temel unsurlarından biri haline gelmiştir. Güven ortamı ekonomilerde belirsizliği azaltmasından dolayı gelecek dönem yatırım ve büyümeyi olumlu etkilemektedir. Dolayısıyla birbirleri ile sıkı ilişkiler içinde olan ekonomik aktörlerin birbirlerine ve genel ekonomik yapıya duymuş oldukları güven istikrarlı büyümenin temelini oluşturmaktadır. 
Ekonomilerin genel dengelerini temsilen makro değişkenler kullanılmaktadır. Büyüme, işsizlik, enflasyon, cari denge, net ihracat temel makro değişkenler olarak kabul edilmektedir. Makro değişkenler ekonominin durumu hakkında bilgi vermekte ve politika yapıcılar bu temel göstergeler doğrultusunda politikalarına yön vermektedirler. Hem politika yapıcıların hem de piyasa dinamiklerinin sayesinde ekonomik dengenin oluşması yönünde gelişmeler yaşanmaktadır. Ekonomik yapıdaki güven ise bu denge ortamının göstergesi olarak kabul edilmektedir.

Ekonomilerdeki güven ortamı, geliştirilen ekonomik güven endeksi ve alt endeksler ile ölçülmektedir. Bu endeksler ekonomideki durumu gösterirken, aynı zamanda gelecek ekonomik planlar hakkında da bilgi vermektedir.

Bu çalışmada Türkiye'nin 2008:M1-2019:M12 yılları arasındaki aylık makro iktisadi göstergelerinin ekonomik güven üzerindeki etkileri ARDL sınır testi yaklaşımıyla analiz edilmiştir. Bu çalışmadaki analizin temel amacı, Türkiye'nin makro iktisadi göstergeleri ile ekonomik güven arasında bir ilişkinin olup olmadığının, varsa bu ilişkinin yönünün tespit edilmesidir.

Yapılan ARDL sınır testi analiz sonuçlarına göre Türkiye'de makro iktisadi değişkenler ile ekonomik güven arasında bir eşbütünleşme ilişkisinin olduğu sonucuna varılmıştır. Dolayısıyla Türkiye'de makro iktisadi değişkenler ile ekonomik güvenin uzun dönemde birbirlerini etkileyebilen değişkenler oldukları belirlenmiştir. Ayrıca yapılan uzun dönemli tahminlerde, makro iktisadi değişkenlerden işsizlik hariç diğer makro iktisadi değişkenler ile ekonomik güven arasındaki ilişkinin \%5 seviyesinde istatistiki açıdan anlamlı olduğu gözlemlenmiştir. Böylece uzun dönem sonuçlarına göre Türkiye'de enflasyon, işsizlik ve ihracat ekonomik güven üzerinde negatif yönlü etkiler oluştururken; sanayi üretimi, reel döviz kuru ve ithalat ise ekonomik güven üzerinde pozitif yönlü etkiler oluşturmaktadır. Son olarak yapılan analizlerde, kısa dönem dengesinde meydana gelen sapmaların yaklaşık olarak 4.1 aylık periyotta yeniden uzun dönem dengesine ulaşacakları sonucuna ulaşılmıştır.

Güven unsuru ekonomiler için vazgeçilmez bir olgudur. Dolayısıyla bir ekonomide güvenin tesis edilmesi, o ülkede ekonomi adına işlerin yolunda gittiğini ve makro iktisadi dinamiklerin temellerinin sağlam olduğunu gösterir. Türkiye'nin makro iktisadi göstergeleri ile ekonomik güven üzerine yapılan bu analiz sonucuna göre enflasyon, işsizlik ve ihracat "ekonomik güven" üzerinde negatif yönlü etkiler oluştururken; sanayi üretimi, reel döviz kuru ve ithalat ise ekonomik güven üzerinde pozitif yönlü etki oluşturmaktadır. Bu sonuçlar tüketicilerin, sektörlerin, yerli ve yabancı yatırımcıların Türkiye'nin ekonomisine olan güven konusunda kafalarının çok karışık olduğunu göstermektedir. Bu durum ise Türkiye ekonomisinde halen istenilen istikrarın yakalanmadığının ve makro iktisadi göstergelerin çok kırılgan bir yapıya sahip olduğunun en açık kanıtıdır. Ayrıca Türkiye'nin ihracatının yıllara göre artarak devam etmesine ve iktisadi büyümenin genelde pozitif olarak ayrışmasına rağmen Türkiye'de halen sürdürebilir ve nitelikli bir ekonomik istikrarın yakalanmadığı görülmektedir. Bu nedenle insanların Türkiye ekonomisine olan kaygıları halen devam etmekte ve güven konusunda ciddi dalgalanmalar yaşanmaktadır.

Bu süreçte Türkiye'nin yapması gereken en önemli şey, nitelikli bir büyüme yakalayarak üretim ve istihdamı arttırmak ve enflasyonu düşürmektedir. Eğer Türkiye bunu gerçekleştirebilirse Türkiye'nin makro iktisadi dinamikleri güçlenecek ve Türkiye ekonomisi bu kırılgan yapıdan hızla kurtulacaktır. Ayrıca Türkiye'de başta ekonomi olmak üzere eğitim, hukuk, vergi sistemi ve sosyal güvenlik gibi alanlarda yapısal reformların acil olarak yapılması gerekmektedir. Üretimi ithal ara girdilere bağımlı olan Türkiye'nin en kısa zamanda ithal ara girdilere olan bağımlılığını azaltarak, mümkünse 
üretimde yerli ara girdilere yönelmesi gerekmektedir. Özellikle Türkiye'nin son yıllarda maruz kaldığı döviz şoklarından kurtulabilmesi için de döviz kurlarında istikrarın yakalanması, bu nedenle kuru dizginleyici politikalara ağırlık vermesi gerekmektedir. Yukarıda değinilen konu ve önerilerin çoğunun yerine getirilmesi durumunda, Türkiye ekonomisine olan güvende istikrara yakalanmıs olacaktır. Güvende istikrarın yakalanması durumunda ise piyasaya yeni yatırımcılar girecek ve ayrıca mevcut yerli ve yabancı yatırımclar yatırımlarını arttıracaklardır. Yeni yatırımlarla birlikte Türkiye'de üretim artacak, yeni istihdam alanları açılacak, işsizlik düşecek ve enflasyonla daha güçlü bir şekilde mücadele edilebilecektir. Dolayısıyla yaşanacak bu tür gelişmeler, Türkiye ekonomisini istikrara giden bir yol ayrımına götürecektir.

Yazar Katkıları: Ş.B. çalışmanın giriş, teorik çerçeve, literatür incelemesi ve veri toplama aşamalarında katkı sağlamıştır. İ.A. çalışmada veri toplama, literatür incelemesi, ekonometrik analiz ve analiz bulgularının raporlanıp yorumlanması ve sonuç aşamalarında katkı sağlamıştır.

Finansman: Bu çalışma için herhangi bir finansal kaynak sağlanmamıştır.

Çıkar Çatışması: Yazarlar arasında herhangi bir çıkar çatışması söz konusu değildir.

\section{Kaynakça}

[1] Bozkaya, Ş., "Güven Faktörü ve Ekonomik Hayata Yansımaları”, Usbık 2020 3.Uluslararası Sosyal Bilimler Kongresi, Isbn: 978-625-400-229-8 Kayseri-Türkiye 29-31 Ocak- January 2020.

[2] http://ingev.org, (E.T.07.04.2021).

[3] www.tuik.gov.tr. (E.T. 10.11.2020).

[4] https://www.economicshelp.org/animal-spirits/, (E.T. 07.04.2021).

[5] Kandır, S. Y. “Tüketici Güveni ve Hisse Senedi Getirileri İlişkisi: İMKB Mali Sektör Şirketleri Üzerinde Bir Uygulama", Ç.Ü. Sosyal Bilimler Enstitüsü Dergisi, C.15, S.2, 2006, ss.217-230.

[6] Korkmaz, T., Çevik, E.İ. “Reel Kesim Güven Endeksi ile İMKB 100 Endeksi Arasındaki Dinamik Nedensellik İlişkisi", İstanbul Üniversitesi İşletme Fakültesi Dergisi. Cilt:38, Sayı:1, 2009, 24-37.

[7] Celik, S., Aslanoglu, E., and Uzun, S., "The Relationship between Consumer Confidence and Financial Market: Variables in Turkey during the Global Crisis".Topics in Middle Eastern and North African Economies, electronic journal, 12, Middle East Economic Association and Loyola University Chicago, 2010,http://www.luc.edu/orgs/meea/

[8] Çelik, S., "An Unconventıonal Analysıs Of Consumer Confıdence Index For The Turkısh Economy", International Journal Of Economics And Finance Studies, Vol 2, No 1, 2010, ISSN: 1309-8055.

[9] Topuz, Y.V. “Tüketici Güveni ve Hisse Senedi Fiyatları Arasındaki Nedensellik İlişkisi: Türkiye Örneği", Ekonomik ve Sosyal Araştırmalar Dergisi. 7, (1): 2011, pp. 53-65.

[10] Aarle, B., and Kappler, M., "Economic sentiment shocks and fluctuations in economic activity in the euro area and the USA", Intereconomics, ISSN 1613-964X, Springer, Heidelberg, Vol. 47, Iss. 1, 2012, pp. 44-51, http://dx.doi.org/10.1007/s10272-012-0405-Z 
[11] Gürgür, T. ve Kılınç, Z. “What Drives the Consumer Confidence in Turkey?”, Research Notes in Economics, V.17, 2015, pp.1-13.

[12] Tunalı, H. ve Özkan, İ. E., “Türkiye'de Tüketici Güven Endeksi ve Tüketici Fiyat Endeksi Arasındaki İlişkinin Ampirik Analizi", İktisat Politikası Araştırmaları Dergisi , C.3, S.2, 2016, ss.53-66.

[13] Kale, S., and Akkaya, M., The Relation between Confidence Climate and Stock Returns: The Case of Turkey, Istanbul Conference of Economics and Finance, ICEF 2015, 22-23 October 2015, Istanbul, Turkey ,Procedia Economics and Finance, 38, 2016, pp. 150 - 162.

[14] Eyüpoğlu, K. ve Eyüpoğlu, S. “Ekonomik Güven Endeksi İle Hisse Senedi Fiyatları Arasındaki İlişkinin İncelenmesi: Türkiye Örneği”, Gazi Üniversitesi İktisadi ve İdari Bilimler Fakültesi Dergisi 19/2 (2017) 603-614.

[15] Evci, S. “Ekonomik Güven Endeksi ile Yatırım Araçları Arasındaki Nedensellik İlişkisi: Toda-Yamamoto Yaklaşımı", İşletme Araştırmaları Dergisi, 11 (4), 2019, ss. 2893-2901.

[16] Aytekin, İ. ve Doyar, V., “Türkiye'de Döviz Kuru Dalgalanmalarının Sanayi Üretimi Ve Tüketici Güveni Üzerindeki Etkisi: (2008-2019)", Hoca Ahmet Yesevi Uluslararası Bilimsel Araştırmalar Kongresi 26-27 Ağustos 2019, Gölbaşı - Adıyaman

[17] Güngör, S. "Ekonomik güven endeksi ve finansal yatırım araçları getirileri arasındaki nedensellik ilişkisi: 2007-2017 döneminde ABD doları ve altın getirileri örneği”. Yönetim ve Ekonomi Araştırmaları Dergisi, 17(1), 2019, 22-39.

[18] Çankaya, S. ve Alp, E. A., “Beklenti Endekslerinin Sanayi Üretimi Üzerine Etkisi”, UIIIIID-IJEAS, 2019 (23):225-236 ISSN 1307-9832.

[19] Aytekin, İ., “Döviz Kuru Sanayi Üretimi ve Ekonomik Güven Arasındaki İlişkinin Analizi: Türkiye Örneği", Bitlis Eren Üniversitesi Sosyal Bilimler Dergisi 2020 9(2) 322-330.

[20] ]https://evds2.tcmb.gov.tr/index.php?/evds/serieMarket, (E.T. 10.11.2020).

[21] Pesaran, Hashem, M. Shin, Yongcheol and Smith Richard J. "Bounds Testing Approaches to the Analysis of Level Relationships". Journal of Applied Econometrics, No: 16, 2001, pp. 289-326. 